\title{
Two new species of Mastogloia Thwaites ex W. Smith (Bacillariophyceae) from Sawa Lake, southern Iraq
}

\author{
Adil Y. Al-Handal ${ }^{1}$, Chiara Pennesi ${ }^{2} \&$ Dawood S. Abdullah ${ }^{1}$ \\ ${ }^{1}$ Department of Marine Biology, Marine Science Centre, University of Basra, Iraq; * Corresponding author: \\ Adil Y.Al-Handal.Email: adil.alhandal@gmail.com \\ ${ }^{2}$ Department of Life and Environmental Sciences, Polytechnic University of the Marche, Via Brecce Bianche, \\ 60131 Ancona, Italy
}

\begin{abstract}
Two new species of the genus Mastogloia are described. Mastogloia sawensis sp. nov. and M. vestigiostriata sp. nov. were encountered as epiphytes on Chara sp. which covers the sediment of Sawa Lake, an isolated saline water body in southern Iraq. Mastogloia sawensis belongs to the section Lanceolatae and is closely similar to M. lanceolata but differs in raphe curvature, areolae shape and arrangement, and the presence of rounded pores at the junction of the partecta. Mastogloia vestigiostriata resembles under light microscopy to M. lyra and M. braunii but shows differences in several features including valve mantle structures, $\mathrm{H}$-shaped lateral hyaline area, siliceous flanges and partectal formation. This study gives morphological details on the ultrastructure of the new species and provides a detailed comparison with all related taxa.
\end{abstract}

Keywords: diatoms, Mastogloia, Sulcatae, Lanceolatae, epiphytic, Sawa Lake, Iraq

\section{INTRODUCTION}

Mastogloia Thwaites ex W. SMith is a large, highly diverse and widespread marine littoral diatom genus that may also found in brackish water (Round et al. 1990). Most species live as epiphytes on macrophytes or attached to submerged objects by mucilage, occasionally aggregated to form colony like structures (STEPHENS \& GIBSON 1980a; YoHN \& GIBSIN 1981, 1982a, b; JoHN 1990; Round 1999; SIVACI et al. 2008; Hein et al. 2008; Pennesi et al. 2011, 2012; LobBan \& Pennesi 2014). In many species, certain extracellular excretions are seen and are almost species specific which serve as attachment tools (HeIN et al. 1993). The most peculiar characteristic of this genus is the presence of a modified valvocopula, genuinely attached to the valve mantle to form a structure called "partectal ring" which runs apically along the inner side of the valve (PADDOCK \& Kemp 1990; Round et al. 1990; Pennesi et al. 2012). Hustedt (1933) grouped all the taxa of the genus into 11 sections and proposed a dichotomous key based only on light microscopy observations (WITKOWSKI et al 2000; Pennesi et al. 2013; Lobban \& Pennesi 2014). Recently, PENNESI et al. $(2011,2012,2013)$ revised the sections Sulcatae and Ellipticae and divided the section Sulcatae into two subgroups to include species exhibiting or not some siliceous external valve outgrowths, such as the conopea and pseudoconopea. Furthermore, small-sized species belonging to the section Ellipticae have been re-described and illustrated through SEM observations to add new morphological information (PENNesi et al. 2013).

Mastogloia is one of the most widely distributed diatoms with more than 410 taxa recorded worldwide (NovARINo 1989). This number, however, is increasing with the recent description of several new taxa (GRAEFF et al. 2013; PENNESI et al. 2011, 2012, 2013; LobBAn \& Pennesi 2014; Lee et al. 2014). A continuous discovery of new Mastogloia taxa may in part due to rapid evolving of the genus in response to varying environmental conditions (PADDOCK \& KEMP 1990).

The southern region of Iraq is characterized by an extensive network of wetlands, including the lower reaches of the Euphrates and Tigris rivers, the Mesopotamian marshes and the Shatt Al-Arab River which extends for $130 \mathrm{~km}$ draining marshes water into the Arabian Gulf. Diatoms in these wetlands have not been extensively studied, with only a few reports on a rather small number of diatom species recorded (HADI et al. 1984; Al-Handal 2009; Al-Handal \& AbDullah 2010). During the last three decades, these wetlands were subjected to increased salinity owing to decreased freshwater discharge from the Tigris and Euphrates rivers as a result of dam construction in some ripari- 
an countries. Brackish environment with a wide distribution of aquatic macrophytes like the wetlands of southern Iraq may form a favorable habitat for diatoms like Mastogloia but only a few number of species were reported, including $M$. apiculata W. Sмгтн, M. braunii Grunow, M. crucicula (Grunow) Cleve, M. elliptica (C. Agardh) Cleve, M. fimbriata (Brightwell) GruNOw, M. pumila (Grunow) Cleve, M. quinquecostata Grunow, M. smithii Thwaites ex W. SMith and M. recta Hustedt (AL-HANDAL 2009). Diatoms in these vast wetlands have not been widely investigated and this small number of taxa may not represent Mastogloia populations.

In this study, two new species of Mastogloia, M. $s a$ wensis and $M$. vestigistriata, are described and classified based on the HustedT's (1933) sections for the genus. These species were found as epiphytes in Sawa Lake, in southern Iraq on the submerged macrophyte Chara sp. which covers almost all bottom sediment of the lake. The aim of this work is to give morphological details on the valve structure of the new taxa and compare their valve features with closely related Mastogloia species using both light and scanning electron microscopy. Moreover, through this work the geographical distribution of the genus has been updated.

\section{Material ANd Methods}

Study site. Sawa Lake $\left(31^{\circ} 18^{\prime} \mathrm{N}, 45^{\circ} 00^{\prime} \mathrm{E}\right)$ is the only natural lake in Iraq. It is located at the eastern edge of the southern desert of Iraq, $22 \mathrm{~km}$ to the west of the Euphrates River and $276 \mathrm{~km}$ south of Baghdad (Figs. 1a, b). The lake area is ca. $10 \mathrm{~km}^{2}$ and surrounded completely by an arid desert at an altitude of $18.6 \mathrm{~m}$ above sea level (NAQASH et al. 1977). The water depth of the lake ranges between 3 to $5.5 \mathrm{~m}$. There is no river discharge to the lake and the only water source is from underground springs flowing in the middle of the lake. It has been found that the Euphrates aquifer feeds the lake through a system of cracks and fissures (JAMIL 1977). The lake water is characterized by a high salinity which far exceeds that of the Euphrates River as a result of an excessive evaporation.

The lake boundaries are formed by a rising salt barrier composed mainly of gypsum which extends for a distance of ca. $13 \mathrm{~km}$. This rim has a rough rugged appearance and look-like stacking of cauliflowers (Fig. 1c). A very narrow shore is found in some parts of the lake and mostly covered with rocky sedimentation. The lake water contains high concentrations of $\mathrm{CaSO}_{4}$ and is a result of the weathering of anhydrite rocks. The bottom of the lake is covered by particles deposited from the atmosphere overlying a hard rock base. Salinity of the lake has increased recently to reach $35 \mathrm{psu}$ as compared to 12 two decades ago (AL-Handal 1994). Owing to the high salt content, it is believed that Sawa Lake water may have a marine origin mixed with underground water (SAMAan 1986). Large patches of the macrophyte Chara sp. cover most of the lake sediment and its fauna which has not been fully investigated, consists of some small fish, zooplankton and other invertebrates (AL-QURAISHI 2013).
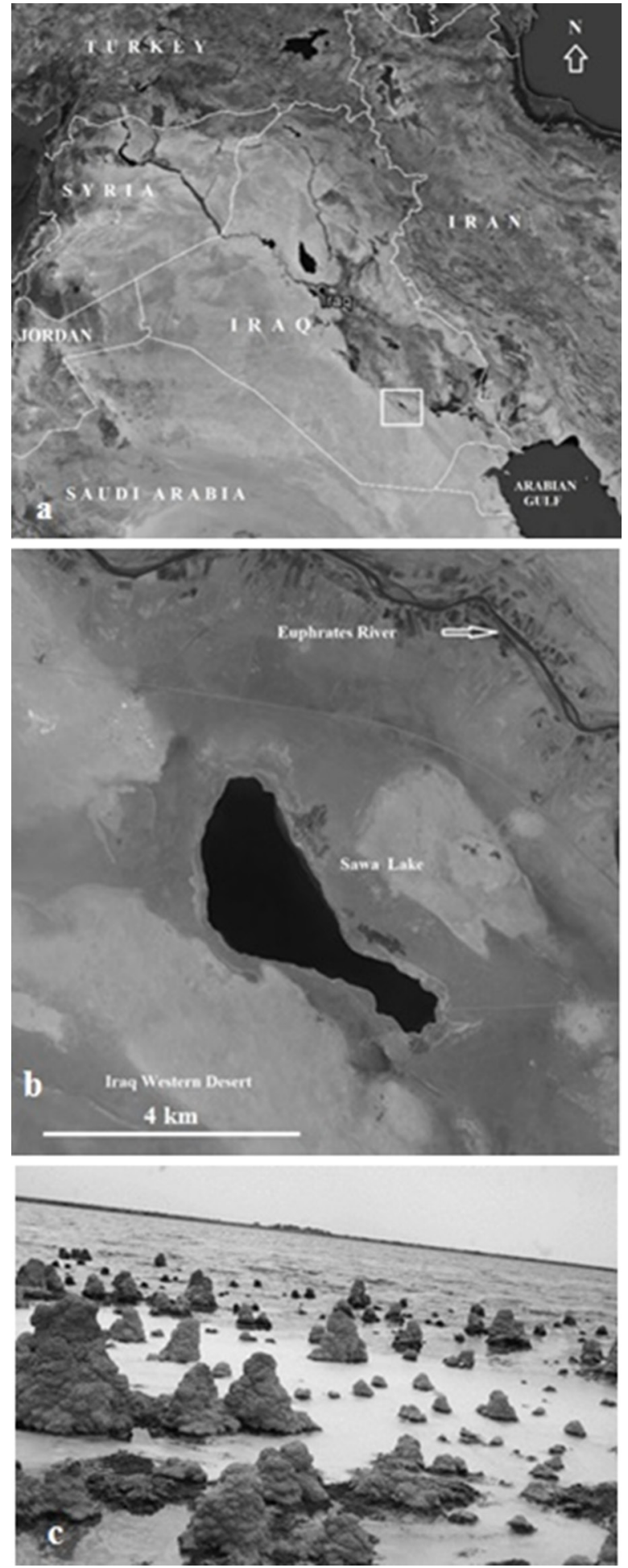

Fig. 1. Location of Sawa Lake (a) in southern Iraq, and (b) its position between the western desert of Iraq and the Euphrates River, with (c) salt deposition mainly formed of gypsum on the lake shore taking the shape of cauliflower stacking.

Samples. Ten samples of Chara sp. were collected on May 2013 from several locations around the lake at depths ranging from 50 to $200 \mathrm{~cm}$. Collection of macrophyte was made by hand. Chara shoots were kept in plastic bottles to which $4 \%$ formalin was added as preservative. In the laboratory, the macrophytes were covered with tap water and shacked 
vigorously to free diatoms which were kept in $50 \mathrm{ml}$ plastic bottles. Diatom samples were first washed with distilled water and then boiled for 10 minutes with $30 \%$ hydrogen peroxide to which few drops of $50 \% \mathrm{HCl}$ were added. After three washes with deionized water to eliminate salts and residues of $\mathrm{HCl}$ and $\mathrm{H}_{2} \mathrm{O}_{2}, 0.5 \mathrm{ml}$ of diatom samples were left to settle and dry on a cover slip before mounting in Naphrax. Light microscope examination and diatom imaging were made under a Zeiss Axioimager A2 microscope. For SEM microscopy, cleaned diatom sample was filtered using $5 \mu \mathrm{m}$ Nuclepore filters, followed by three washings with deionised water. The filters were then air-dried and mounted on aluminum stubs before coating with gold palladium alloy. Examination was made under Hitachi S-4500 SEM operated at 15 $\mathrm{kV}$ (College of Marine Science, University of South Florida, Saint Petersburg, USA).

\section{Observations}

Mastogloia sawensis Al-Handal et Pennesi sp. nov. (SEM Figs 2a-h, 3a-d, LM Fig. 6a-d)

Diagnosis: Valves lanceolate with subrostrate apices, 47.3-72.3 $\mu \mathrm{m}$ long, $17-21.4 \mu \mathrm{m}$ wide. Transapical striae, $26-34$ in $10 \mu \mathrm{m}$. Raphe branches strongly sinuous. Partecta distributed nearly to the apices along each side of the partectal ring. Rectangular partecta of uniform size (2.6-3 $\mu \mathrm{m}$ wide) with single rounded pores located at the junction of the partectal ring with the valve margin (5-6 on each side).

Holotype: Slide BM 710784 from material collected as epiphyte on Chara sp. in Sawa Lake, southern Iraq, deposited in the Natural History Museum, London, U.K. Fig. 6a represents the holotype.

Isotype: Slide SL52015, Department of Marine Biology, Marine Science Center, Basra, Iraq.

Type locality: Lake shore, Sawa Lake, southern Iraq $\left(31^{\circ} 18^{\prime} \mathrm{N}, 45^{\circ} 00^{\prime} \mathrm{E}\right)$.

Etymology: The specific epithet refers to the geographic location where this species was found.

Description: Valves are lanceolate with subrostrate apices (Figs 2a, c, d, f, h, 3a, c, d, 6a-d). External raphe branches are strongly sinuous (Figs $2 \mathrm{a}, \mathrm{f}, 3 \mathrm{c}$ ), ending centrally in co-axial pores deflected in the same direction (Figs 2a, b, f, 3c) and distally in hooked terminal fissures (Fig. 2a, c, f). The raphe-sternum includes a small transapically elongated central area (Figs 2a, arrowhead, b, f, 3c). Internally, the raphe branches are straight, ending centrally in raised simple pores and distally in a small helictoglossa, and they are bordered by siliceous and linear ribs, which are slightly transapically dilated at the centre to form a distinct central nodule (Figs 2d, arrowhead, e, h, 3a, b, d). Transapical striae are parallel and absent near the poles (Figs 2a, c, f, 3c). Striae are uniseriate and consist externally of rounded areolae, except for apically oriented slitlike areolae near the raphe-sternum (Fig. 2b, c), and rounded areolae continuing down the mantle (Fig. 3c). Areolae are occluded by vela. Partecta are distributed almost up to the apices along each side of the partectal ring which opens through a lacuna at poles, small septa are present at the far end of each pole (Figs $2 \mathrm{~d}, \mathrm{f}, \mathrm{h}$, arrowhead, 3a, d, arrowhead). Rectangular partecta are elongated transapically, similar in size and shape except for the near apical ones which are irregular (Figs $2 \mathrm{~d}, \mathrm{f}-\mathrm{h}, 3 \mathrm{a}$ ). They are linear on the free margin (Figs $2 \mathrm{~d}, \mathrm{f}-\mathrm{h}, 3 \mathrm{a}$ ), with no visible ornamentation except for five or six rounded pores at the junction of the partecta with the valve margin (Fig. 2g, arrowhead, h). Partecta open externally through apical partectal pores (Fig. 3c, arrowhead).

\section{Mastogloia vestigiostriata Al-Handal et Pennesi sp. nov. (SEM Figs 4a-h, 5a-d, LM Fig. 6e-h)}

Diagnosis: Valves lanceolate to elliptical-lanceolate with subrostrate to rounded apices, 44.1-58 $\mu \mathrm{m}$ long, 16.1-20 $\mu \mathrm{m}$ wide. Transapical striae, $15-18$ in $10 \mu \mathrm{m}$. Raphe branches strongly sinuous. External valve face with shallow semi-elliptical to linear median depression on both sides of the raphe-sternum. Partecta displaced toward middle of the valve by a siliceous flange. Quadrangular partecta of uniform size (1.9-2.2 $\mu \mathrm{m}$ wide), not reaching apices.

Holotype: Slide BM 101785 from material collected as epiphyte on Chara sp. in Sawa Lake, southern Iraq, deposited in the Natural History Museum, London, U.K. Fig. 6e represents the holotype.

Isotype: Slide SL52016, Department of Marine Biology, Marine Science Center, Basra, Iraq.

Type locality: Lake shore, Sawa Lake, southern Iraq $\left(31^{\circ} 18^{\prime} \mathrm{N}, 45^{\circ} 00^{\prime} \mathrm{E}\right)$.

Etymology: The specific epithet refers to the vestigial striae occurring on the external valve depressions.

Description: Valves are lanceolate to elliptical-lanceolate with subrostrate to rounded apices (Figs 4a, c, $\mathrm{d}, \mathrm{f}, \mathrm{g}, 5 \mathrm{a}, \mathrm{c}, 6 \mathrm{e}-\mathrm{h})$. The external raphe branches are strongly sinuous (Figs 4a, f, 5a), ending centrally in slightly expanded pores deflected in the same direction (Fig. 4a, b, f) and distally in terminal fissures bent toward the same side (Figs 4a, d, f, 5a). The raphesternum is transapically expanded at the centre into a quadrangular area with some sign of rounded areola irregularly arranged (Figs 4a, arrowhead, b, f, 5a). The internal raphe branches are straight, ending centrally as simple pores (Figs 4c, e, 5c) and distally in small helictoglossae, and they are bordered by silicious ribs (Figs 4c, 5c). The valve face shows externally two distinct zones consisting of a shallow semi-elliptical to linear median depression restricted to both sides of the raphe-sternum, and an outer zone reaching the valve margin (Figs 4a, f, 5a). Transapical striae vary from parallel at the centre to radiate at the ends, and are absent near the poles (Figs 4a, d, f, 5a). Striae are unise- 


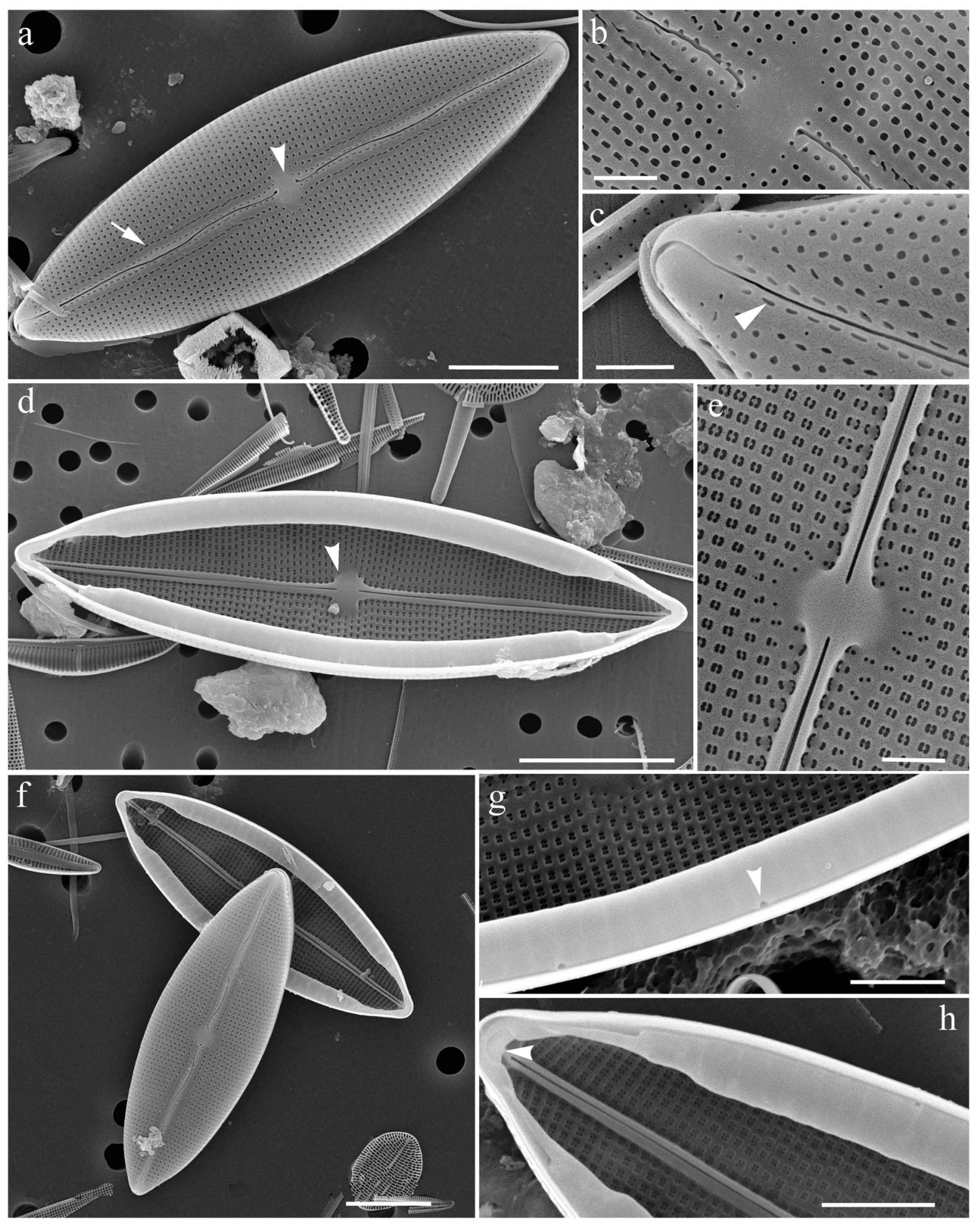

Fig. 2. Mastogloia sawensis sp. nov., SEM: (a) complete valve in external view showing the central area (arrowhead) and strongly sinuous raphe branches; (b) detail on transapically elongated central area in external view; (c) apex in external view showing hooked terminal raphe fissure; (d) internal view of a complete valve showing central nodule (arrowhead) and partectal ring; (e) detail of central nodule; (f) dissociated frustule showing external and internal valves; (g) partecta showing rounded pores on the wall (arrowhead); (h) internal view of apex with small septum (arrowhead) and lacuna. Scale bars $10 \mu \mathrm{m}(\mathrm{a}, \mathrm{d}, \mathrm{f}) ; 5 \mu \mathrm{m}(\mathrm{g}, \mathrm{h}) ; 2 \mu \mathrm{m}(\mathrm{b}, \mathrm{c}, \mathrm{e})$. 


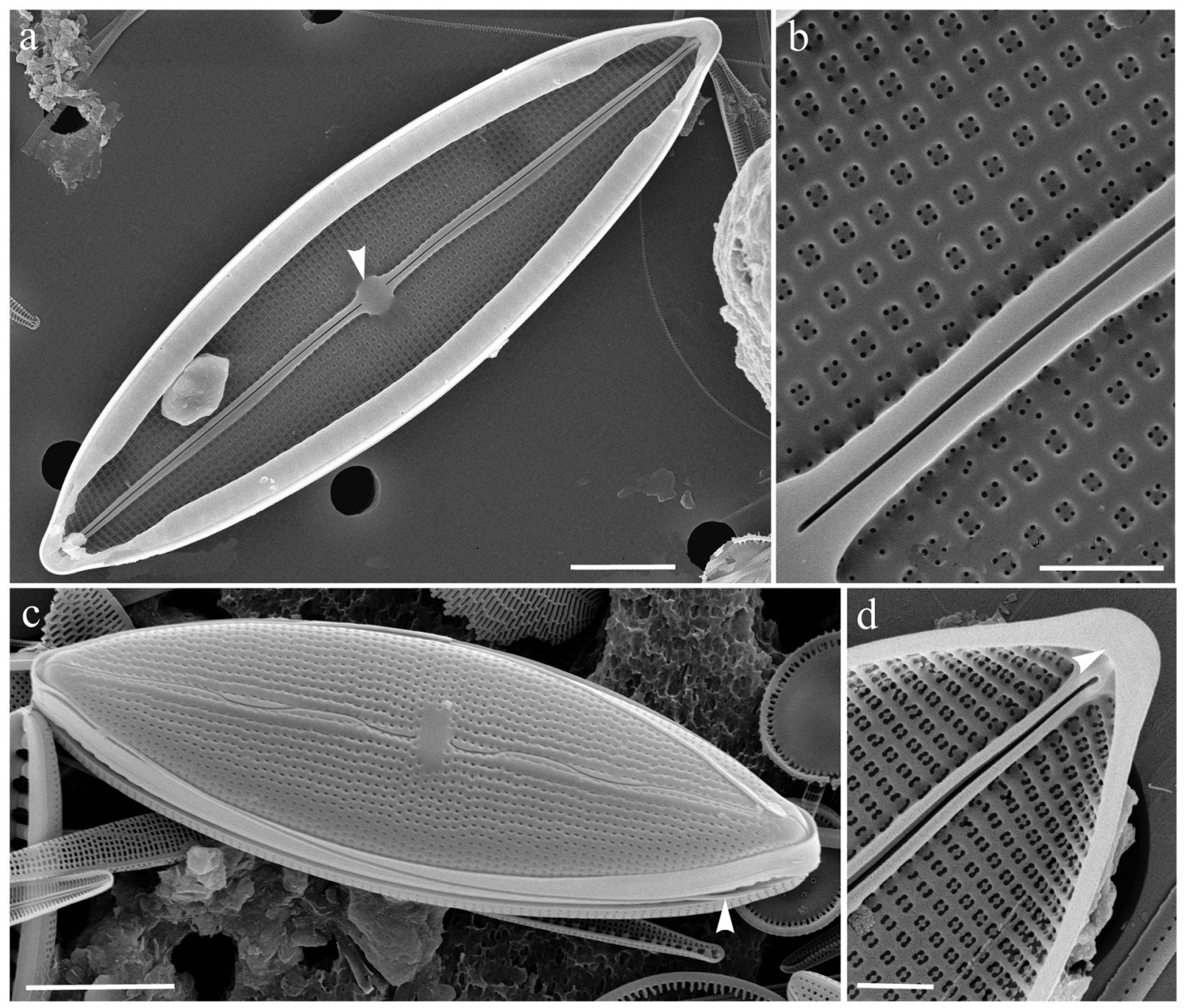

Fig. 3. Mastogloia sawensis sp. nov., SEM: (a) internal valve view showing partectal ring and central nodule (arrowhead); (b) detail on internal areolae forming the striae; (c) external view of a tilted valve with partectal pores (arrowhead) on the valvocopula; (d) internal view of apex showing small septum (arrowhead). Scale bars $10 \mu \mathrm{m}(\mathrm{a}, \mathrm{c}) ; 2 \mu \mathrm{m}(\mathrm{b}, \mathrm{d})$.

riate and consist externally of rather rounded areolae, except for more or less transapically elongated areolae forming vestigial striae at the end of the median depression (Figs 4a, d, f, 5a, b). Rounded areolae are present on the mantle (Figs 4f, 5a). Areolae are occluded by rota-like velum. The external valve face is characterized by several wavy and irregular longitudinal thickenings on the margin (Figs 4a, f, 5a). Internally, the valve surface shows a narrow, $\mathrm{H}$-shaped hyaline lateral sternum in the same position occupied by the external valve median depression (Figs 4c, 5c). The silicified costa-like interstriae are visible near the raphe system and beyond the inner median zone (Figs 4c, e, h, 5c, d). Partecta are distributed along the each side of the whole partectal ring almost up to the apices, opening at poles through a cleft (Fig. 4c, g, arrowhead). Quadrangular partecta are similar in size and shape and attached to each side of the valvocopula with a broad siliceous flange (Fig. 4c, h, arrowhead). Partecta are slightly convex on the free margin (Fig. 4c, h) and ornamented with pores arranged inwardly in short para- llel rows only in the middle partectal areas (Figs 4c, g, h), opening externally through partectal pores (Figs 4f, arrowhead, 5a, arrowhead).

\section{Discussion}

Mastogloia sawensis sp. nov. belongs to HustedT's (1933) section Lanceolatae based on its valve features. This section includes taxa that always show lanceolate valves and partecta with same size and shape, except for the ones nearer to the poles. Species in this section also possess a partectal ring on the valvocopula and areolae forming striae rarely that are arranged to form an irregular quincunx pattern on the valve surface (e.g., M. tenuissima HustedT). In LM, M. sawensis sp. nov. appears similar to $M$. lanceolata ThwAItEs ex W. SMiтH sharing a similar valve outline, partectal ring (Fig. 2d, f, Hustedt 1933, Stephens \& Gibson 1980a) and shape 

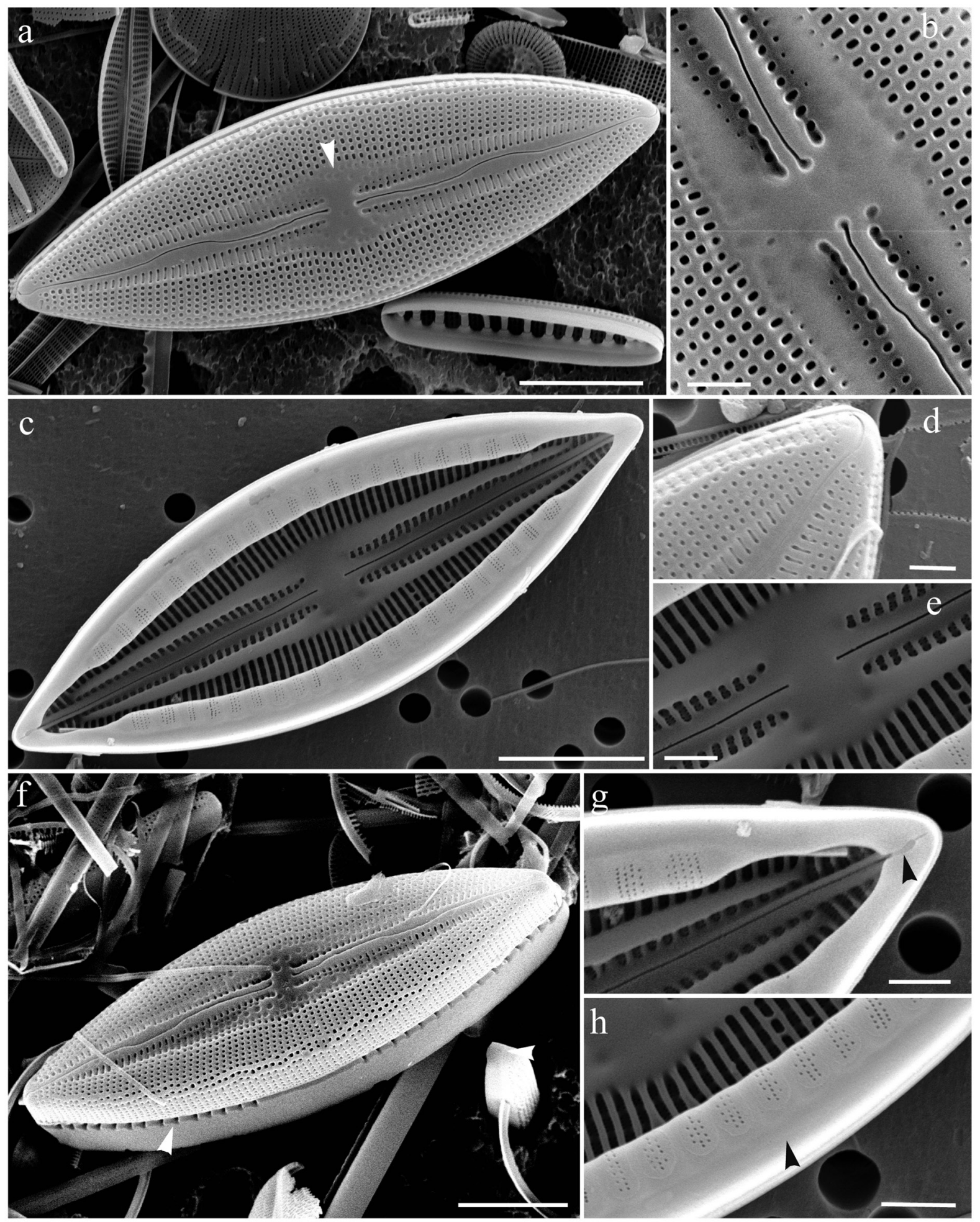

Fig. 4. Mastogloia vestigiostriata sp. nov., SEM: (a) external valve view showing median depression and central area (arrowhead); (b) detail on the central area in external view; (c) Internal valve view showing the partectal ring with flange and $\mathrm{H}$-shaped hyaline lateral sterna; (d) external view of apex showing bent terminal raphe fissure; (e) detail of internal central valve; (f) external view of tilted valve showing median depression and partectal pores (arrowhead); (g) internal view of apex with cleft (arrowhead); (h) detail on partecta and siliceous flange (arrowhead). Scale bars $10 \mu \mathrm{m}(\mathrm{a}, \mathrm{c}, \mathrm{f}) ; 5 \mu \mathrm{m}(\mathrm{h}) ; 2 \mu \mathrm{m}(\mathrm{b}, \mathrm{d}, \mathrm{e}, \mathrm{g})$. 


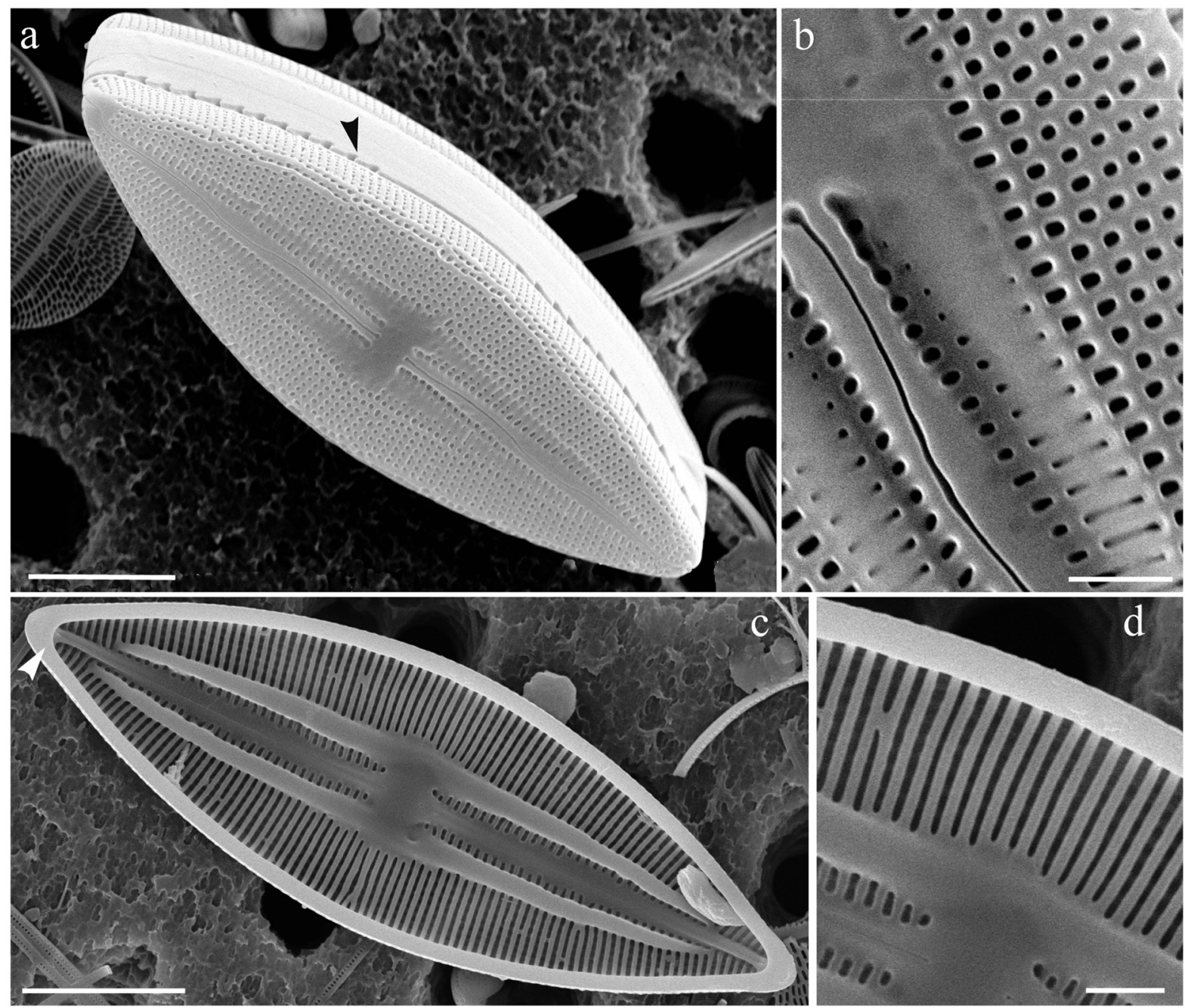

Fig. 5. Mastogloia vestigiostriata sp. nov., SEM: (a) external view of tilted valve showing partectal pores (arrowhead) and longitudinal irregular thickenings on the margin; (b) detail of external areolae forming the striae; (c) internal view of the valve without partectal ring showing septum (arrowhead); (d) detail on internal interstriae. Scale bars $10 \mu \mathrm{m}(\mathrm{a}, \mathrm{c}) ; 2 \mu \mathrm{m}(\mathrm{b}, \mathrm{d})$.

of areolae forming the striae (Fig. 2a, b, STEPHENS \& GiBSON 1980a). However, M. lanceolata has slightly undulate or slightly bent raphe fissures while in $\mathrm{M}$. $\mathrm{sa}$ wensis the raphe branches are strongly sinuous (Figs 2a, f, 3c). In the external valve face of M. lanceola$t a$, the transapical striae are parallel to slightly radiate near the centre of the valve, becoming convergent near the apices (Hustedt 1933; Stephens \& Gibson 1980a), while in M. sawensis, the transapical striae are parallel on the entire valve (Fig. 2a, f). Unlike M. lanceolata which possesses rounded areolae (STEPHENs \& Gibson 1980a, Figs 17, 18), M. sawensis exhibits two rows of slit-like areolae on both sides of the raphe-sternum (Figs 2a, arrow; 2c, arrowhead) which are not rounded like on the remaining part of the valve. In M. sawensis, there are rounded pores at the junction of the partecta with the valve margin (Fig. $2 \mathrm{~g}$ ) while in M. lanceolata this character seems to be absent and has never been reported previously (e.g. Hustedt 1933; STEPHENS \& GiBSON 1980a; SnOEIIS \& PotaPova 1995). These rounded pores are also visible on the partectal ring of $M$. smithii
Thwaites ex W. Smith, M. pseudosmithii Lee, Gaiser, Van de Vijver, Edlund et Spaulding (Lee et al. 2014), M. acutiuscula (Grunow) Cleve (RicARD 1975), and M. apiculata W. Smith (Stephens \& Gibson 1980a).

Mastogloia sawensis, can be compared with M. aquilegiae Grunow in A. SChMiDt 1893 which has similar valve shape and partecta but differs in some features of the external valve face. M. aquilegiae shows externally transapical and longitudinal ribs (Hustedt 1933; Foged 1980; Archibald 1983; GASSE 1986) which are missing in our new species (Fig. 2a, f). Number of the transapical striae is less in M. aquilegiae than in our new taxon. Moreover, partecta is wider in M. aquilegiae (HustedT 1933; ARCHIBALD 1983) than in M. sawensis. In our new species there are two rows of slit-like areolae on both sides of the raphe-sternum (Figs 2a, arrow; 2c, arrowhead) that are missing in M. aquilegiae (HUSTEDT 1933; FoGED 1980; ARCHIBALD 1983; GASSE 1986). Mastogloia sawensis also bears a resemblance to M. fallax CLEVE (1895) for its valve shape and the type of partecta but 

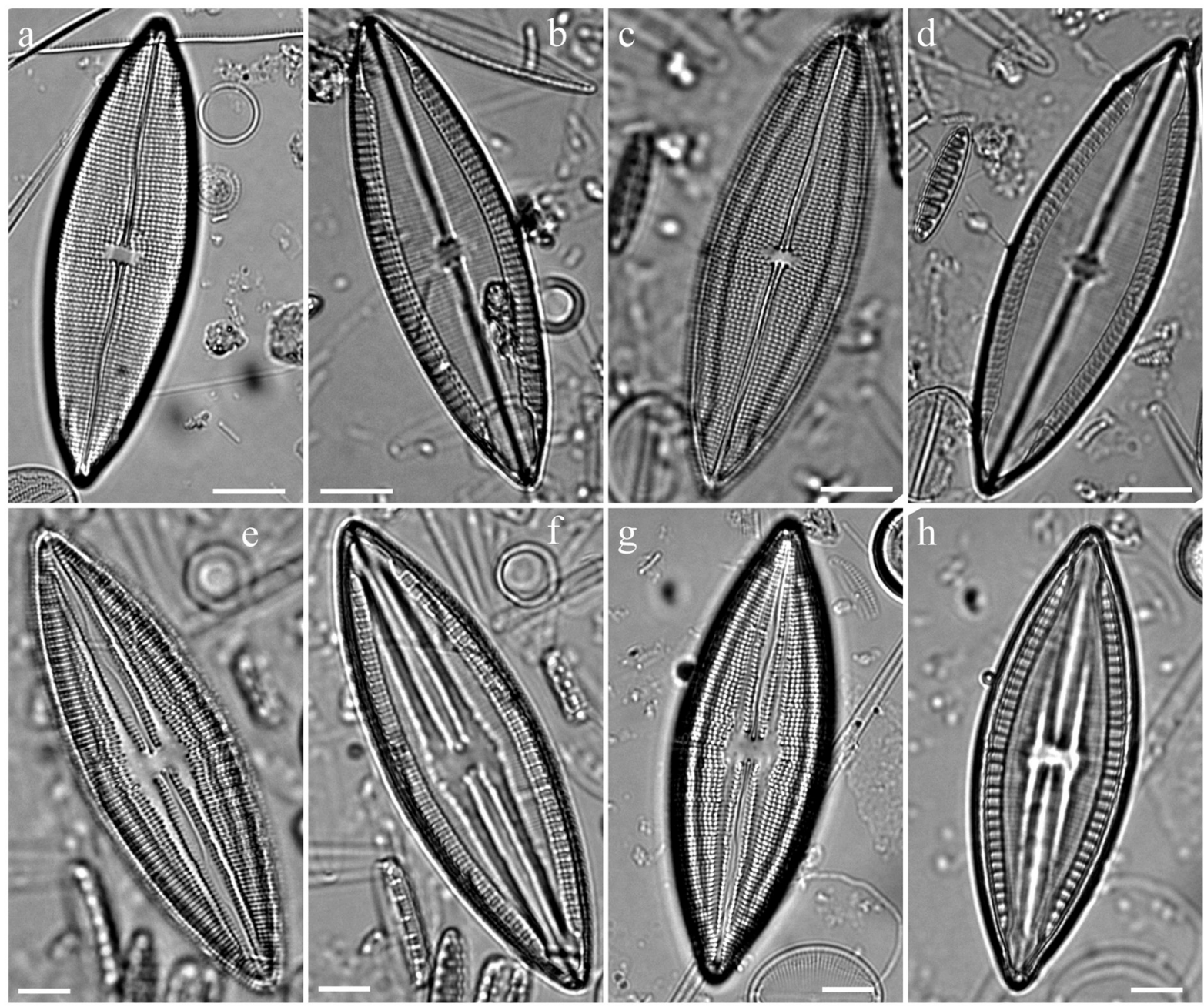

Fig. 6. Two new species of Mastogloia from Sawa Lake, Iraq, LM: (a-d) Mastogloia sawensis, (a) holotype; (e-h) Mastogloia vestigiostriata, (e) holotype. Scale bars $10 \mu \mathrm{m}(\mathrm{a}-\mathrm{d}) ; 5 \mu \mathrm{m}(\mathrm{e}-\mathrm{h})$.

they show some different characters. M. fallax has a slightly wavy raphe branches (HUSTEDT 1933) while in $M$. sawensis the raphe is strongly sinuous. The external valve face of $M$. fallax shows straight to slightly wavy longitudinal ribs (HustedT 1933), which are missing in M. sawensis. CLEVE (1895) reported 16 transapical striae in $10 \mu \mathrm{m}$ in M. fallax, while Hustedt (1933) reported 24-27 striae in $10 \mu \mathrm{m}$, a highly different striae density. M. sawensis, however, is more close to HusTEDT's description.

The new species $M$. vestigiostriata belongs to HusTEDT's (1933) section Sulcatae for its slight depression on the external valve surface (Fig. 4f) and to subgroup 2 recently described by PenNesi et al. (2012) who divided the section Sulcatae into two subgroups: (1) species where the median depressions can be or are covered by two different siliceous external outgrowths called conopea and pseudoconopea, and (2) species having only a median depression in the inner zone of the external valve face. The $\mathrm{H}$-shaped hyaline lateral sterna showed in internal view for M. vestigiostriata (Figs 4c,
$5 c)$ is an important morphological character in the HusTEDT's section Sulcatae. However, some of the species belonging to Sulcatae do not show this character (e.g. $M$. cannii KemP et PADDOCK, M. baldjikiana GRUNOw, M. borneensis Hustedt, M. hustedtii MeIster, M. neoborneensis PenNesi et TotTI and M. oculoides PenNesi et Poulin). Mastogloia vestigiostriata has a siliceous flange (Fig. 4h, arrowhead) which displaced the partectal ring toward the middle line of the valve. Usually, the partectal flange is typically reported for species belonging to the section Paradoxae (HustedT 1933), but even if rare, it has been already recorded in only one species of the section Sulcatae, M. lyra LoBBAn et PENNESi (LobBAn \& PenNesi 2014). Hustedt (1933) considers the siliceous flange as a peculiar and characteristic feature for the section Paradoxae, but after LoBBAn \& PenNesi (2014) and the discovery of this feature in $M$. vestigiostriata, this character is present in the section Sulcatae too.

Mastogloia vestigiostriata can be compared with $M$. lyra, sharing a similar valve outline (elliptical to elliptical-lanceolate), but with different shape of the 
apices. In M. vestigiostriata, the apices are subrostrate to rounded, while in M. lyra they are rounded. The frustule size of these two species is different with $M$. vestigiostriata larger and wider than M. lyra. Externally, $M$. vestigiostriata shows a shallow semi-elliptical to linear median depression on both sides of the raphesternum (Fig. 4a, f), while in M. lyra the depressions are very narrow, different in shape, and ornamented with different areolae (LobBan \& PenNesi 2014, figs 37, 43). Internally, both species possess a siliceous flange (Figs 4c, h, Lobban \& Pennesi 2014, fig. 40), but the oblique partectal ducts are missing in $M$. vestigiostriata. The two species have similar partecta shape and size, but with different $\mathrm{H}$-shaped hyaline lateral sterna, which are larger in $M$. vestigiostriata than in $M$. lyra (Fig. 4c, LobBan \& Pennesi 2014, fig. 40).

Mastogloia vestigiostriata shows some similarities with $M$. braunii Grunow sharing a similar valve outline and external valve surface (i.e., type of areolae, strongly sinuous raphe branches and "H-configuration" structure). Mastogloia braunii, however, can be longer and larger than M. vestigiostriata. The appearance of the valve mantle differs between these two species. In M. braunii, it has two longitudinal rows of areolae where the first row is formed by slit areolae and the second one by rounded areolae (STEPHENS \& GIBSON 1980b, fig. 3), whereas in M. vestigiostriata, the mantle is composed by rounded areolae arranged in transapical rows (Figs 4f, 5a). The longitudinal and irregular thickenings on the margin present in $M$. vestigiostriata (Figs 4a, 5a) are missing from the valves of $M$. braunii (Stephens \& Gibson 1980b, fig. 4). The other different feature is that $M$. vestigiostriata has quadrangular partecta, uniform in size and shape, and attached to each side of the valvocopula with a broad siliceous flange (Fig. 4a), while in M. braunii the partecta are different in size with an enlarged central partectum, and the partecta are becoming narrower toward the ends of the valve (STEPHENS \& GiBSON 1980b, fig. 5). In M. braunii, the siliceous flange is reduced to a thin intercalary band (STEPHENS \& GiBSON 1980b).

The two new species described in this study were found in an isolated desert lake, Sawa Lake, with a high salt content. These two species have not been encountered in the surrounding water bodies or may have been misidentified by other workers as they may be easily confused with allied taxa as described above. However, the finding of these species would add to our knowledge on the benthic diatoms of Iraq which we only have little information about.

\section{ACKNOWLedgments}

The authors wish to thank the Marine Science Centre, Basra for providing field and laboratory equipment. Thanks are also due to $\mathrm{Mr}$. Tony Greco, University of South Florida (USF), USA, for his help in SEM. The first author wishes to express his gratitude to Prof. J. Dixon and Prof. C. Hu of the Faculty of Marine Science, University of South Florida for their invitation to visit and use the faculty faci- lities to accomplish this work. The visit to USF was financed by the International Institute of Education.

\section{REFERENCES}

ArchiBald, R.E.M. (1983). The diatoms of the Sundays and great fish rivers in the Eastern Cape province of South Africa. - Bibliotheca Phycologica 49: 1-136.

Al-Handal, A.Y. (1994): Contribution to the knowledge of diatoms of Sawa Lake, Iraq. - Nova Hedwigia 59: $225-254$.

Al-Handal, A.Y. (2009): Littoral diatoms from the Shatt Al-Arab estuary, North West Arabian Gulf. - Cryptogam. Algol. 30: 153-183.

Al-Handal, A.Y. \& Abdulla, D.S. (2010): Diatoms from the restored Mesopotamian, South Iraq. - Algological Studies 133: 65-103.

AL-Quraishi, R.I.M. (3013): Hydrogeochemistry of Sawa Lake, Southern Iraq [M.Sc. Thesis]. - 184 pp., University of Baghdad, Iraq.

Cleve, P.T. (1895). Synopsis of the Naviculoid Diatoms, Part II. - Kongliga Svenska-Vetenskaps Akademiens Handlingar 27: 1-219, 4 pls.

Foged, N. (1980). Diatoms in Oland, Sweden. - Bibliotheca Phycologica 49: 1-122.

GASSE, F. (1986). East African diatoms; taxonomy, ecological distribution. - Bibliotheca Phycologica 11: 1-75.

GraefF, C.L.; Kociolek, J.P. \& Rushforth, S.R. (2013): New and interesting diatoms (Bacillariophyta) from Blue Lake Warm Springs, Tooele County, Utah. - Phytotaxa 153: 1-38.

HADI, R.A.M.; AL-SABOONCHI, A.A. \& HaRoON, A.K.Y. (1984): Diatoms of the Shatt

Al- Arab river at Basrah, Iraq. - Nova Hedwigia 39: 513-555.

Hein, M.K.; Winsborough, B.M.; Davis, J.S. \& Golubic, S. (1993): Extracellular structures produced by marine species of Mastogloia. - Diatom Res. 8: 73-88.

Hein, M. K.; Winsborough, B.M. \& Sullivan, M.J. (2008): Bacillariophyta (diatoms) of the Bahamas. - Iconogr. Diatomol. 19: 1-303.

Hustedt, F. (1933): Die Kieselalgen Deutschlands, Österreichs und der Schweiz. - In: Rabenhorst's Kryptogamenflora, Band 7, Teil 2, Leif. 4. - pp. 433576, Johnson Reprint, New York.

JAMIL, A.K. (1977): Geological and hydrogeochemical aspects of Sawa Lake S. Iraq. - Bull. Coll. Sci. 18: 221-253.

JoHn, J. (1990): The diatom flora of the microbial communities associated with stromatolites at Shark Bay, Indian Ocean, West Coast of Australia. - In: RicARD, M. (ed.): Ouvrage dédié à H. Germain. - pp. 97-110, Koeltz Scientific Books, Königstein, Germany.

Kemp, K.D. \& PAdDock, T.B.B. (1990): A description of two new species of the diatom genus Mastogloia with further observations on M. amoyensis and M. gieskesii. - Diatom Res. 5: 311-323.

Lee, S.S.; Gaiser, E.E.; VAn de viJver, B.; Edlund, M.B. \& Spaulding, S.A. (2014): Morphology and typification of Mastogloia smithii and M. lacustris, with descriptions of two new species from the Florida Everglades and the Caribbean region. - Diatom Res. 29: 325350 . 
Lobban, C.S. \& Pennesi, C. (2014). Two new Mastogloia species (Bacillariophyceae), $M$. parlibellioides and $M$. lyra, from coral reefs in Guam, Western Pacific. - Bot. Mar. 57: 41-54.

Lobban C.S.; Schefter, M.; Jordan, R.W.; Arai, Y.; SasaKI, A.; Theriot, E.C.; Ashworth, M.; Ruck, E.C. \& Pennesi, C. (2012): Coral-reef diatoms (Bacillariophyta) from Guam: new records and preliminary checklist, with emphasis on epiphytic species from farmer-fish territories. - Micronesica 43: 237-479.

Naqash, A.B.; Banat, K. \& Al-shamee, F. (1977): Geological, hydrochemical and sedimentlogical petrographical study of Sawa Lake. - Bull. Coll. Sci. 18: 199220.

Novarino, G. (1989): An update of the taxa of the genus Mastogloia, with a "resemblanc list" for the more recently described ones. - Diatom Res. 4: 319-343.

Paddock, T.B.B. \& Kemp, K.D. (1990): An illustrated survey of the morphological features of the diatom genus Mastogloia. - Diatom Res. 5: 73-103.

Pennesi, C.; Poulin, M.; De stefano, M.; Romagnoli, T. \& Tотті, C. (2011): New insights to the ultrastructure of some marine Mastogloia species section Sulcatae (Bacillariophyceae), including $M$. neoborneensis sp. nov. - Phycologia 50: 548-562.

Pennesi, C.; Poulin, M.; De stefano, M.; Romagnoli, T. \& Tотті, C. (2012): Morphological studies of some marine Mastogloia (Bacillariophyceae) belonging to section Sulcatae, including the description of new species. - J. Phycol. 48: 1248-1264.

Pennesi, C.; Poulin, M.; Hinz, F.; Romagnoli, T.; De stefaNo, M. \& Tотті, C. (2013): Comparison of two new species of Mastogloia (Bacillariophyceae) with other small members of section Ellipticae. - Phytotaxa 126: $1-21$

RICARD, M. (1975): Ultrastructure de quelques Mastogloia (diatomées benthiques) marines d'un lagon de Tahiti. - Protistologica 11: 49-60.

Romagnoli, T.; Bavestrello, G.; Cucchiari, E.; De stefano, M.; Di Camillo, C.; Pennesi, C.; Puce, S. \& Totti, C. (2007): Microalgal communities epibiontic on the marine hydroid Eudendrium racemosum in the Ligurian Sea during an annual cycle. - Mar. Biol. 151: 537-552.

Romagnoli, T.; Totti, C.; Accoroni, S.; De stefano, M. \& Pennesi, C. (2014): SEM analysis of the epibenthic diatoms on Eudendrium racemosum (Hydrozoa) from the Mediterranean Sea. - Turk. J. Bot. 38: 566594.

Round, F.E.; Crawford, R.M. \& Mann, D.G. (1990): The diatoms. Biology and morphology of the genera. 747 pp., Cambridge University Press, New York.

SAmaAN, S.Y. (1986): Geochemistry and mineralogy of the Samawa saltern southern Iraq [M.Sc. Thesis]. - 183 pp., University Baghdad, Iraq.

Schmidt, A.; Schmidt, M.; Fricke, F.; Heiden, H.; Müller, O. \& Hustedt, F. (1874-1959): Atlas der Diatomaceen-Kunde. - 120 pp., 460 pls., Aschersleben Leipzig, Berlin.

Sivaci, E.R.; CanKa, Y.A.E.; Kilmc, S. \& Dere, S. (2008): Seasonal assessment of epiphytic diatom distribution and diversity in relation to environmental factors in a karstic lake Central Turkey. - Nova Hedwigia 86:
215-230.

Sмiтh, W. (1856): Synopsis of British Diatomaceae. - John Van Voorst, London. 2:107 pp., pls. 32-60, 61-62, A-E.

Snoeiss, P. \& Potapova, M. (1995)(eds): Intercalibration and distribution of diatom species in the Baltic sea. - In: Baltic Marine Biologists Publication 16c. - 126 pp., Opulus Press, Uppsala.

Stephens, F.C. \& GibSON, R.A. (1980a): Ultrastructural studies of some Mastogloia (Bacillariophyceae) species belonging to the groups Undulatae, Apiculatae, Lanceolatae and Paradoxae. - Phycologia 19: 143-152.

Stephens, F.C. \& Gibson, R.A. (1980b): Ultrastructural studies of some Mastogloia (Bacillariophyceae) species belonging to the group Sulcatae. - Nova Hedwigia 33: 219-244.

Witkowski, A.; Lange-Bertalot, H. \& Metzeltin, D. (2000): Diatom flora of marine coasts I. - Iconogr. Diatomol. 7: 1-925.

Yohn, T.A. \& Gibson R.A. (1981): Marine diatoms of the Bahamas. I. Mastogloia Thw. ex Wm. Sm. species of the groups Lanceolatae and Undulatae. - Bot. Mar. 24: 641-655.

Yohn, T.A. \& Gibson R.A. (1982a): Marine diatoms of the Bahamas. II. Mastogloia Thw. ex Wm. Sm. species of the groups Decussatae and Ellipticae. - Bot. Mar. 25: 41-53.

Yohn, T.A. \& Gibson R.A. (1982b): Marine diatoms of the Bahamas. III. Mastogloia Thw. ex Wm. Sm. species of the groups Inaequales, Lanceolatae, Sulcatae and Undulatae. - Bot. Mar. 25: 277-288.

(C) Czech Phycological Society (2015)

Received January 20, 2015

Accepted April 18, 2015 